\title{
Reconciling surface ocean productivity, export fluxes and sediment composition in a global biogeochemical ocean model
}

\author{
M. Gehlen ${ }^{1}$, L. Bopp ${ }^{1}$, N. Emprin ${ }^{1}$, O. Aumont ${ }^{2}$, C. Heinze ${ }^{3}$, and O. Ragueneau ${ }^{4}$ \\ ${ }^{1}$ LSCE/IPSL, Laboratoire des Sciences du Climat et de l'Environnement, CEA-CNRS-UVSQ Orme des Merisiers, Bât. 712, \\ CEA/Saclay 91198 Gif-sur-Yvette Cedex, France \\ ${ }^{2}$ LOCEAN/IPSL, Centre IRD de Bretagne, BP 70, 29280 Plouzané, France \\ ${ }^{3}$ University of Bergen, Geophysical Institute \& Bjerkness Centre for Climate Research, Allegaten 70, 5007 Bergen, Norway \\ ${ }^{4}$ Institut Universitaire Européen de la Mer, Place Copernic, Technopôle Brest-Iroise, 29280 Plouzané, France
}

Received: 24 April 2006 - Published in Biogeosciences Discuss.: 28 June 2006

Revised: 26 October 2006 - Accepted: 6 November 2006 - Published: 9 November 2006

\begin{abstract}
This study focuses on an improved representation of the biological soft tissue pump in the global threedimensional biogeochemical ocean model PISCES. We compare three parameterizations of particle dynamics: (1) the model standard version including two particle size classes, aggregation-disaggregation and prescribed sinking speed; (2) an aggregation-disaggregation model with a particle size spectrum and prognostic sinking speed; (3) a mineral ballast parameterization with no size classes, but prognostic sinking speed. In addition, the model includes a description of surface sediments and organic carbon early diagenesis. Model output is compared to data or data based estimates of ocean productivity, pe-ratios, particle fluxes, surface sediment bulk composition and benthic $\mathrm{O}_{2}$ fluxes. Model results suggest that different processes control POC fluxes at different depths. In the wind mixed layer turbulent particle coagulation appears as key process in controlling pe-ratios. Parameterization (2) yields simulated pe-ratios that compare well to observations. Below the wind mixed layer, POC fluxes are most sensitive to the intensity of zooplankton flux feeding, indicating the importance of zooplankton community composition. All model parameters being kept constant, the capability of the model to reproduce yearly mean POC fluxes below $2000 \mathrm{~m}$ and benthic oxygen demand does at first order not dependent on the resolution of the particle size spectrum. Aggregate formation appears essential to initiate an intense biological pump. At great depth the reported close to constant particle fluxes are most likely the result of the combined effect of aggregate formation and mineral ballasting.
\end{abstract}

\footnotetext{
Correspondence to: $\mathrm{M}$. Gehlen

(marion.gehlen@cea.fr)
}

\section{Introduction}

There are two pathways for the drawdown of carbon from the surface ocean and its removal from the ocean reservoir: the production of particulate organic carbon (POC) during photosynthesis and the formation of carbonate shells (PIC) during biomineralization, followed by the sinking of these particles out of surface ocean waters and their incorporation to surface sediments. Both pathways affect the surface ocean carbonate system and thus air-sea exchanges of $\mathrm{CO}_{2}$ in contrasting ways. During photosynthesis dissolved inorganic carbon (DIC) is consumed together with nutrients to form POC thereby decreasing the $\mathrm{pCO}_{2}$ of surface ocean waters. The resulting DIC deficit is filled by $\mathrm{CO}_{2}$ released by respiration of POC either in surface waters or mixed up from deeper layers and exchanged with the atmosphere. The time scales at which $\mathrm{C}$ bound into POC is subtracted to air-sea exchange depends on its depth of remineralization. Conceptually, time scales range from days for shallow remineralization in well mixed waters to geological time scales for the fraction buried in marine sediments. The production and export of POC is referred to as "the biological pump" (Volk and Hoffert, 1985). The precipitation of PIC as hard parts of carbonate shells increases the $\mathrm{pCO}_{2}$ of surface waters (carbonate counter-pump). Particulate inorganic $\mathrm{C}$ penetrates deeper in the water column compared to POC. Its dissolution releases alkalinity which in turn titrates part of the $\mathrm{CO}_{2}$ released during POC respiration. Moreover, recent studies suggest that PIC is the main carrier phase of POC to the deep ocean (Armstrong et al., 2002; Francois et al., 2002; Klaas and Archer, 2002).

The past decade has witnessed the rapid development of global ocean biogeochemical models. The growing

Published by Copernicus GmbH on behalf of the European Geosciences Union. 
awareness of the role of biology in the shaping of biogeochemical fluxes and its potential evolution in response to global climate change is at the origin of increasingly complex descriptions of the surface ocean ecosystem up to the first level of consumers. State-of-the-art models (Aumont and Bopp, 2006; Le Quéré et al., 2005; Moore et al., 2004) now distinguish between different plankton functional types (silicifiers, $\mathrm{N}$-fixing plankton, calcifiers, zooplankton of different size-classes) and co-limitation by macro- and micronutrients $(\mathrm{Fe})$. Despite these advances, the fate of export production is still mostly described in a rather simplified way by imposing empirical functions (e.g. Suess, 1980; Betzer et al., 1984; Martin et al., 1987; Armstrong et al., 2002) to describe the distribution of particulate matter across the water column.

While export fluxes are differentiated by their chemical composition (e.g. POC, PIC and biogenic opal), marine particles are of diverse origin and composition. They range from individual plankton cells or fecal pellets to complex aggregates made of different types of primary particles trapped in a mucilaginous matrix. Fluxes of marine particles display strong regional and temporal variability in response to production regimes and their seasonality. There is growing evidence that upper ocean ecosystems contrasting in terms of primary productivity, f-ratio, seasonality etc. are characterized by quite different efficiencies in terms of $\mathrm{C}$ transfer to the meso- and bathypelagos. These relationships need to be taken into account in order to correctly assess effects of future changes in ecosystem structure and export fluxes on atmospheric $\mathrm{CO}_{2}$ exchange, as well as to quantify the potential of artificial $\mathrm{Fe}$ fertilization as a sink for $\mathrm{CO}_{2}$.

In this paper, we compare and evaluate three different schemes of particle flux parameterizations for their use in biogeochemical global circulation models: The PISCES standard version (two size classes, aggregationdisaggregation, prescribed sinking speed), an aggregationdisaggregation model (particle size spectrum, prognostic sinking speed), a mineral ballast parameterization (no size classes, prognostic sinking speed). We aim at an integrated representation of material fluxes from the productive surface ocean down to the sediment-water interface. This enables to take advantage of the variety of observations available for model output - data comparison.

\section{Model description}

\subsection{The biogeochemical global ocean model}

The biogeochemical model used in the study is PISCES (Aumont and Bopp, 2006), which is based on HAMOCC5 (Aumont et al., 2003). It simulates the biogeochemical cycles of oxygen, carbon and of the three main nutrients controlling marine phytoplankton growth: phosphate, silicate and iron. The model is built on the assumption that phytoplankton growth is limited by the external availability in nutrients.
A complete description of the model, as well as a basic validation of the main model output can be found in Aumont and Bopp (2006).

The model distinguishes two phytoplankton sizeclasses/functional types corresponding to nanophytoplankton and diatoms, and two zooplankton size-classes which are microzooplankton and mesozooplankton. For all species, the $\mathrm{C} / \mathrm{N} / \mathrm{P}$ ratios are assumed constant. Prognostic variables of phytoplankton are total biomass in carbon, iron, chlorophyll and silicon (for diatoms). As a consequence, the internal $\mathrm{Fe} / \mathrm{C}, \mathrm{Chl} / \mathrm{C}$, and $\mathrm{Si} / \mathrm{C}$ ratios are fully prognosed by the model. For zooplankton, all these ratios are supposed constant and thus, the total biomass in carbon is the only prognostic variable. The bacterial pool is not modeled explicitly.

The PISCES standard version distinguishes three nonliving organic carbon compartments: semi-labile dissolved organic carbon (DOC) with timescales of several weeks to several years, two size classes of particulate organic carbon ( small particles $=\mathrm{POC}_{s}$ and big particles $\left.=\mathrm{POC}_{b}\right)$. While the $\mathrm{C} / \mathrm{N} / \mathrm{P}$ composition of dissolved and particulate matter is tied to Redfield stochiometry, the iron, silicon and carbonate contents of the particles are computed. Next to the three organic detrital pools, carbonate and biogenic siliceous particles are modeled.

In addition to the ecosystem description, PISCES simulates dissolved inorganic carbon and total alkalinity (carbonate alkalinity + borate + water). The carbon chemistry is computed following the OCMIP protocols (http://www.ipsl. jussieu.fr/OCMIP). Finally, the phosphorus and the nitrogen cycles are decoupled in the model by nitrogen fixation and denitrification. These two processes are modeled in PISCES according to simplified parameterizations, which are fully described in Aumont and Bopp (2006).

\subsection{Particle flux parameterizations}

All model versions share the same description of processes producing or consuming particles, including aggregation (Kriest and Evans, 1999, 2000). Particulate organic detritus is produced by mortality, fecal pellet production, grazing and aggregation between dissolved and particulate organic carbon pools. Mineralization of particulate organic carbon together with excretion contributes to the semi-labile pool of dissolved organic carbon. Mineralization of POC is temperature dependent.

The model accounts for the production of carbonate shells (calcite) by nanophytoplankton as a function of environmental conditions (temperature, light, nutrient availability). The pool of sinking calcite particles is fueled by mortality of nanophytoplankton, as well as by zooplankton grazing on nanophytoplankton. Fifty percent of the carbonate taken in during grazing is routed to the pool of sinking particles, the remainder is supposed to dissolve in the guts of grazers. This description was implemented to account for the reported high 
dissolution rates above the lysocline (e.g. Milliman et al., 1999; Iglesias-Rodriguez et al., 2002). Dissolution of PIC occurs in response to undersaturation with respect to calcite following the kinetic expression proposed by Maier-Reimer (1993). Mortality and grazing on diatoms contribute to the pool of biogenic $\mathrm{Si}(\mathrm{BSi})$. The dissolution of $\mathrm{BSi}$ is described as a function of temperature and undersaturation following Ridgwell et al. (2002).

The aggregation model which is implemented in PISCES is based on Jackson (1990) and Kriest and Evans (1999, 2000). This approach relies on the assumption that the particle number distribution $p(\theta)$ can be represented by a power law as a function of particle diameter $\theta$ (McCave, 1984):

$p(\theta)=\frac{d N}{d \theta}=A \theta^{-\varepsilon} \quad m<\theta<\infty$

where: $d N$, number concentration of particles in a given size range $\theta$ to $\theta+d \theta$;

$\varepsilon$, dimensionless power value of particle size spectra.

Aggregation is promoted by turbulent shear and differential settling of particles. The equation governing the rate of collision $(\zeta)$ between particles described by number distributions $p(\theta)$ and $p(\Theta)$ over the size range from $m$ to $\infty$ is

$\xi=0.5 \alpha \int_{m}^{\infty} \int_{m}^{\infty}\left(\beta_{\text {shear }}(\theta, \Theta)+\beta_{\text {sett }}(\theta, \Theta)\right) p(\theta) p(\Theta) d \theta d \Theta$

where: $\alpha$, parameter of particle stickiness (non dimensional); $\beta(\theta, \Theta)$, rectiliniear collision kernel for turbulent (shear) and differential settling (sett);

$p(\theta), p(\Theta)$, particle number distributions.

The stickiness corresponds to the probability of two particles to stick together after collision. The collisions due to shear and differential settling are evaluated following Kriest (2002).

Biological and physical processes modify mass and number of particles either one by one or both together. For instance, aggregation among particles will modify their number without modifying total mass, while fecal pellet production will in turn add numbers and mass. Flux feeding (Jackson, 1993) is yet another example of the complex interactions between particle fluxes and biology (Stemmann et al., 2004a). Flux feeding is a feeding type attributed to mesozooplankters in which the rate of particle collecting scales with the concentration of falling particles and their sinking speed, thus their flux. Flux feeding modifies the mass and the number of particles, along with changing their size through particle fragmentation. A model study by Stemmann et al. (2004b) suggests that the decrease of flux in the mesopelagos is largely controlled by flux feeding mesoplankton. The process is implemented to the PISCES model based on the following parameterization:

$g^{\text {meso }}(\mathrm{POC})=g_{F F}^{\text {meso }} w^{\mathrm{POC}} \frac{[\mathrm{POC}]}{K_{\mathrm{POC}}^{F F}+[\mathrm{POC}]}$

where $g_{F F}^{\text {meso }}$, maximum rate of flux feeding, $1 / \mathrm{m}$ $K_{\mathrm{POCb}}^{F F}$, half saturation constant for flux feeding, $\mu \mathrm{mol} \mathrm{C/l}$
$w^{\mathrm{POCb}}$, sinking velocity of POC, $\mathrm{m} / \mathrm{d}$

POC, concentration of POC, $\mu \mathrm{mol} \mathrm{C/l}$

Flux feeding does not increase infinitively with flux. This behaviour is accounted for by a Michaelis-Menten type function. Flux feeding varies in time and space in response to the changing abundance of mesozooplankton computed by the model. Details on how the interactions between flux feeding and the sinking flux of POC are described in the different model version are given below.

2.2.1 Standard version: two particle size classes, prescribed sinking speed

In the PISCES standard version, the two POC size classes $\mathrm{POC}_{s}$ (= small) and $\mathrm{POC}_{b}$ (= big) are fueled by mortality of nanophytoplankton and diatoms, fecal pellet production, grazing and aggregation between $\mathrm{DOC}, \mathrm{POC}_{s}$ and $\mathrm{POC}_{b}$. Aggregation transfers carbon from the semi-labile DOC pool to the small particles $\left(\phi_{\mathrm{agg}}^{\mathrm{DOC} \rightarrow \mathrm{POCs}}\right)$ and to the big particles $\left(\phi_{\mathrm{agg}}^{\mathrm{DOC} \rightarrow \mathrm{POCb}}\right)$. While Eq. (2) applies to continuous distributions described by a particle size spectrum, the model standard version distinguishes large and small POC produced by large, respectively small plankton. We grouped modelled particles into 4 discrete classes of particles: nanophytoplankton, diatoms and microzooplankton, mesozooplankton, aggregates. For each particle class the corresponding size range and average size are summarized in Table 1 . The corresponding aggregation terms write:

$$
\begin{aligned}
\phi_{\mathrm{agg}}^{\mathrm{DOC} \rightarrow \mathrm{POCs}}= & \phi_{1}^{\mathrm{DOC}_{s}} s \cdot \mathrm{DOC}^{2}+\phi_{2}^{\mathrm{DOC}} s h \cdot \mathrm{DOC} \cdot \mathrm{POC}_{s} \\
\phi_{\mathrm{agg}}^{\mathrm{DOC}} \rightarrow \mathrm{POCb}= & \phi_{3}^{\mathrm{DOC}_{s}} s \cdot \mathrm{DOC} \cdot \mathrm{POC}_{b} \\
\phi_{\mathrm{agg}}^{\mathrm{POC} \rightarrow \mathrm{POCb}}= & \phi_{1}^{\mathrm{POCs}} s h \cdot \mathrm{POC}_{s}^{2}+\phi_{2}^{\mathrm{POCs}} s h \cdot \mathrm{POC}_{b} \cdot \mathrm{POC}_{s} \\
& +\phi_{3}^{\mathrm{POC}_{\mathrm{s}}} \mathrm{POC}_{s}^{2}+\phi_{4}^{\mathrm{POCs}} s h \cdot \mathrm{POC}_{b} \cdot \mathrm{POC}_{s}
\end{aligned}
$$

The shear rate $(s h)$ is set to $1 \mathrm{~s}^{-1}$ in the mixed layer and $0.01 \mathrm{~s}^{-1}$ below. The coefficients $\phi$ $\left(\phi_{1}^{\mathrm{DOC}}, \phi_{2}^{\mathrm{DOC}}, \phi_{3}^{\mathrm{DOC}}, \phi_{1}^{\mathrm{POCs}}, \phi_{2}^{\mathrm{POC}}\right.$ for turbulence coagulation; $\phi_{3}^{\mathrm{POCs}}, \phi_{4}^{\mathrm{POCs}}$ for differential settling) were computed by integrating the standard rectilinear kernels for collisions (Kriest, 2002) over the size range of each organic matter pool. The power value of the number spectra (Eq. 1) was set to 3.28 (Kriest, 2002). This number was derived assuming a fractal dimension of 2.28 for the aggregates and a constant mass distribution over the size range of the corresponding particle size class.

The sinking speed is prescribed in this model version. To account for the reported increase with depth of sinking speed (Berelson, 2002), the following parameterisation is applied to the sinking speed of $\mathrm{POC}_{b}\left(w^{\mathrm{POC}}, \mathrm{m} / \mathrm{d}\right)$ :

$w^{\mathrm{POC}}=w_{\min }^{\mathrm{POC}}+\left(w_{\max }^{\mathrm{POC}}-w_{\min }^{\mathrm{POC}}\right) \max \left(0, \frac{z-z_{m}}{2000}\right)$

where: $w_{\min }^{\mathrm{POC}}$, minimum sinking speed of $\mathrm{POC}_{b}, 50 \mathrm{~m} / \mathrm{d}$; $w_{\text {max }}^{\text {POC }}$, maximum sinking, $200 \mathrm{~m} / \mathrm{d}$;

$z_{m}$, depth of mixed layer. 
Table 1. Size range of particle classes identified in the model and corresponding average size. The number equivalent of size class in terms of single cells.

\begin{tabular}{llll}
\hline Particle type & size range $(\mu \mathrm{m})$ & average size $(\mu \mathrm{m})$ & number equivalent \\
\hline nanophytoplankton & $2-20$ & 6.32 & 2.3 \\
Diatoms, microzooplankton & $10-200$ & 45 & 3.7 \\
mesozooplankton & $200-2000$ & 632 & 7.0 \\
aggregate & $200-5000$ & 1000 & 9.9 \\
\hline
\end{tabular}

Hard shell remains (PIC and BSi) fall with the same sinking speed as the fraction of large organic particles. The fraction of $\mathrm{POC}_{s}$ sinks at a constant speed of $3 \mathrm{~m} / \mathrm{d}$. Flux feeding by mesozooplankton occurs preferentially on fast falling particles (Jackson, 1993). This preference was taken into account by limiting it to $\mathrm{POC}_{b}$. It decreases the flux of fast sinking larger particles and modifies the average sinking speed of POC in the model.

\subsubsection{Parameterization of size spectrum: number and mass} of particles, prognostic sinking speed

In comparison to the standard version of PISCES, we have implemented a more advanced description of particle dynamics based on the work by Kriest and Evans (1999, 2000). This approach models the size distribution of particles of the detrital pool and their mean sinking speed based on the assumption that the particle size spectrum can be fully described by the number and the mass of particles. The sinking speed is computed as a function of the particle size spectrum. The number concentration of particles in a size class $\theta$ to $\theta+d \theta$ follows from the particle size distribution (Eq. 1). The cumulative size distribution is derived from Eq. (1) as the integral over the range of particle sizes $m$ to $\infty$. It yields the total number of particles $P(m)$ larger than $m$ and reads:

$$
P(m)=A \int_{m}^{\infty} \theta^{-\varepsilon} d \theta=A \frac{m^{1-\varepsilon}}{\varepsilon-1} \text { provided } \varepsilon>1 .
$$

Let the mass $C$ of a particle be related to its diameter $\theta$ by $C(\theta)=C \theta^{\zeta}$ and $C_{m}=C m^{\zeta}$ be the mass of a single cell. The total mass of particles follows from the cumulative mass distribution $M(\theta)$ as

$$
M(m)=A C \int_{m}^{\infty} \theta^{\zeta-\varepsilon} d \theta=A C_{m} \frac{m^{1+\zeta-\varepsilon}}{(\varepsilon-\zeta-1)}
$$$$
\text { provided } \varepsilon>\zeta+1 \text {. }
$$

The exponent $\varepsilon$, the shape of the size distribution, is expressed as a function of $N$, the average number of cells in an aggregate

$N=\frac{M(m)}{P(m) C_{m}}=\frac{\varepsilon-1}{\varepsilon-1-\zeta}$ thus $\varepsilon=\frac{(1+\zeta) N-1}{N-1}$.
Sinking modifies the number and the mass of particles in a given parcel of water. The sinking flux of numbers and mass are

$$
\begin{aligned}
& \phi(z)=\int_{m}^{\infty} p(z, \theta) \omega(\theta) d \theta, \text { respectively } \\
& \psi(z)=C \int_{m}^{\infty} p(z, \theta) \theta^{\zeta} \omega(\theta) d \theta
\end{aligned}
$$

where $\omega(\theta)=B \theta^{\eta}$ is the sinking speed of a particle of size $\theta$.

Aggregation changes the size spectrum, but does not affect particle mass. As in the PISCES standard version, aggregation results from turbulent shear and differential settling. The rate of particle collision ( $\zeta$ ) follows from Eq. (2). In contrast to the PISCES standard version which distinguishes four discrete particle size classes, a continuous particle number spectrum is computed in this case. Equations (2), (9) and (10) are solved over the finite size spectrum used in this study and their implementation in a vertically resolved model follow Kriest and Evans (2000). Parameter values are summarized in Table 2.

Biological processes like grazing and mortality add to the pool of particles (POC) and modify the mass and size distributions. For instance, flux feeding by mesozooplankton on the POC flux modifies the particle size spectrum by the transfer of mass from big to small particles. Each of the four plankton types encompasses a variety of species and thus a size spectrum. To account for the contribution of the four living compartments to the particle number distribution, we calculated the average size of each pool and its individual cell number equivalent (Table 1). For particles bigger than the single cell, but that are no aggregates, the contribution to $P(m)$ is less than that of aggregates of the same size. The dynamic particle mass and number distributions describe the evolution of the detrital pool (POC). The remaining two classes of particles biogenic silica and carbonate are described as in the standard version. Their sinking speed is however no longer imposed. In this version, the hard shell parts sink with the same velocity as computed for the detrital pool. 
Table 2. Parameter values of PISCES-K\&E.

\begin{tabular}{lll}
\hline Parameter & units & PISCES K\&E \\
\hline sinking exponent $(\eta)$ & dimensionless & 1.17 \\
sinking factor $(\mathrm{B})$ & $\mathrm{m}^{-0.17} / \mathrm{d}$ & 942 \\
particle mass - diameter exponent $(\zeta)$ & dimensionless & 2.28 \\
Stickiness & dimensionless & 0.5 \\
mass of single cell & $\mathrm{g}$ & 0.0002 \\
upper limit of aggregate mass & $\mathrm{g}$ & 1.0 \\
shear (mixed layer) & $1 / \mathrm{s}$ & 1.0 \\
shear (below mixed layer) & $1 / \mathrm{s}$ & 0.01 \\
\hline
\end{tabular}

2.2.3 Mineral ballast model: no information on particle size, prognostic sinking speed

This model version does not distinguish between particle size classes. Aggregation is described as detailed under Sect. 2.2.1. The sinking speed is prognostic and follows from the average excess density of the particle pool computed from its mean composition in terms of biogenic silica, carbonate and organic matter. The excess density is given by

$\rho_{\text {excess }}=$

$\frac{m_{\mathrm{POC}}[\mathrm{POC}]+m_{\mathrm{CaCO}_{3}}\left[\mathrm{CaCO}_{3}\right]+m_{\mathrm{BSi}}[\mathrm{BSi}]}{m_{\mathrm{POC}} / \rho_{\mathrm{POC}}[\mathrm{POC}]+{ }^{m \mathrm{CaCO}_{3}} / \rho_{\mathrm{CaCO}_{3}}\left[\mathrm{CaCO}_{3}\right]+{ }^{m} \mathrm{BSi} / \rho_{\mathrm{BSi}}[\mathrm{BSi}]}-\rho_{S W}$

where: $m_{\mathrm{POC}}, m_{\mathrm{CaCO} 3}, m_{\mathrm{BSi}}$, molecular weight of POC (32.7 g), $\mathrm{CaCO}_{3}(100 \mathrm{~g})$ and biogenic silica (72.8 g);

[POC], $\left[\mathrm{CaCO}_{3}\right]$, [BSI], molar concentration of $\mathrm{POC}$, $\mathrm{CaCO}_{3}$ and biogenic silica;

$\rho_{\mathrm{POC}}, \rho_{\mathrm{CaCO}}, \rho_{\mathrm{BSi}}, \rho_{\mathrm{SWi}}$, density of POC $\left(1.06 \mathrm{~g} / \mathrm{cm}^{3}\right)$, $\mathrm{CaCO}_{3}\left(2.71 \mathrm{~g} / \mathrm{cm}^{3}\right)$, biogenic silica $\left(2.10 \mathrm{~g} / \mathrm{cm}^{3}\right)$ and density of seawater $\left(1.027 \mathrm{~g} / \mathrm{cm}^{3}\right)$.

The sinking speed follows from $w_{\text {ballast }}=3\left(\rho_{\text {excess }} / \rho_{\text {POC }}-\rho_{S W}\right)$, where the lower limit of sinking speed is set to $3 \mathrm{~m} / \mathrm{d}$. All particles sink at the same calculated sinking speed.

\subsection{The surface sediments}

The fluxes of $\mathrm{POC}_{s}, \mathrm{POC}_{b}, \mathrm{BSi}$ and $\mathrm{CaCO}_{3}$ reaching the sediment-water interface are incorporated to the bioturbated sediment layer and undergo early diagenesis as described by Heinze et al. (1999). Within the sediment compartment the two size classes of POC are no longer distinguished. In the original model by Heinze et al. (1999), POC is mineralized solely by oxygen reduction. We added denitrification to the set of early diagenetic reactions. In the model set-up selected for this study, the sediment compartment is not coupled interactively to the water column, but run in an off-line mode. Parameter values are as in Heinze et al. (1999).

\section{Methodology}

\subsection{Set-up of model experiments}

The 3-D global ocean general circulation model OPA (Madec et al., 1998) provided the physical forcing fields for tracer transport. After 3000 years of integration, PISCES reached a quasi steady-state with a mean state and seasonal variations similar to those observed for nutrients and chlorophyll. A comprehensive comparison between modeled dissolved properties (e.g. nutrients, alkalinity, DIC) and data is given in the auxiliary material of Aumont and Bopp (2006). This reference state corresponds to the simulation identified as STD3 in this study. It was the starting point for 5 model experiments. For each experiment the model was integrated over 100 years. While this integration time is too short to equilibrate the deep ocean with respect to changes in the particle flux parameterization, it is justified in the context of a study focusing on the description of particle dynamics and an integrated representation of the biological pump from the surface ocean to the sediment-water interface. Particle fluxes can, at first order, be considered as 1-D properties. Their response time to changes in parameterization is thus independent of the general adjustment time of dissolved tracers and shorter.

The reference version of this study is labeled STD1. A second set of experiments addressed the sensitivity of mid- and deep-water water fluxes to the aggregation (STD2) and the parameterization of zooplankton feeding (STD3) while keeping the configuration of the standard version. Experiment 4 corresponds to the full aggregation/disaggregation model (K\&E, particle size spectrum, prognostic sinking speed), while experiment 5 represents the mineral ballast parameterization (BAL, no information on particle size, prognostic sinking speed). An overview of model experiments is given in Table 3. For each of the 5 scenarios, yearly mean fluxes of $\mathrm{POC}, \mathrm{BSi}, \mathrm{CaCO}_{3}$ and clay were used together with yearly averaged bottom water compositions to equilibrate the surface sediments in an off-line mode. After $50 \mathrm{ky}$ of integration stable distributions of solid and dissolved sediment tracers were obtained. 
Table 3. Model experiments.

\begin{tabular}{lclll}
\hline $\begin{array}{l}\text { Experiment ID } \\
\text { PISCES }\end{array}$ & Aggregation & Particle size classes & Sinking speed & Flux feeding geso $(\mathrm{m} / \mathrm{d})$ \\
\hline STD1 & & & & \\
STD2 & yes & two & prescribed & $3.5 \times 10^{-4}$ \\
STD3 & no & two & prescribed & $3.5 \times 10^{-4}$ \\
K\&E & yes & two & prescribed & $7.0 \times 10^{-4}$ \\
BAL & yes & full spectrum & prognostic & $3.5 \times 10^{-4}$ \\
& yes & ignored & prognostic & $3.5 \times 10^{-4}$ \\
\hline
\end{tabular}

\subsection{Model evaluation}

The biogeochemical model PISCES was tested over different time ranges and in various studies: paleoclimatology (Bopp et al., 2003), iron fertilization experiments (Aumont and Bopp, 2006), climate change (Bopp et al., 2005). For this study we selected remote sensing data (SeaWIFS, average surface chlorophyll in $\mathrm{mg} / \mathrm{m}^{3}$ over 1997-2004), estimates of the pe-ratio (primary production over export production) at the base of the euphotic zone (Dunne et al. (2004), data available as auxiliary material), sediment trap POC fluxes (refer to Fig. 3 for location and depth of sediment traps; data are available under http://www.pangea.de, Dittert et al., 2005), surface sediment bulk composition (\% dry weight $\mathrm{CaCO}_{3}$, $\mathrm{SiO}_{2}$, Corg from http://www.pangea.de, Dittert et al., 2005) and oxygen fluxes at the sediment-water interface (Jahnke, 1996) for model evaluation. Sediment trap data were not Thcorrected. We selected only data from traps deployed over at least a year and at depths greater than $1000 \mathrm{~m}$, but at least $500 \mathrm{~m}$ above the seafloor. While the trapping efficiency of traps deployed in the mesopelagic zone is in general lower than 1 , the corresponding efficiency fluctuates around 1 in the bathypelagos (depth >1200 m) (Yu et al., 2001).

\section{Results and discussion}

Model results are presented and compared to data on Figs. 1 to 6: chlorophyll distributions for May and November (Fig. 1), pe-ratios (Fig. 2), POC fluxes across the water column (Fig. 3), surface sediment bulk composition (Figs. 4 and 5) and benthic $\mathrm{O}_{2}$ fluxes (Fig. 6). Table 4 summarizes global numbers (primary production, export fluxes, etc.) for each model scenario and presents available independent estimates. These bulk numbers allow a first evaluation of model performance. A detailed discussion of individual model scenarios follows later.

Model derived annual primary production range from $21 \mathrm{GT}$ C/y (PISCES-BAL) to 43 GT C/y (PISCES-STD3). Carr et al. (2006) compared global values of net primary production computed from ocean color. A total of 24 algorithms were compared and corresponding estimates ranged from below $40 \mathrm{GT} \mathrm{C} / \mathrm{y}$ to over $60 \mathrm{GT} \mathrm{C} / \mathrm{y}$, with an average of $50.7 \mathrm{GT} \mathrm{C} / \mathrm{y}$. Taking into account the spread of remote sensing based estimates, modeled annual primary production compares favorably to the later in the case of PISCES-STD3 and PISCES-K\&E. To the contrary, model versions STD1, STD2 and BAL underestimate global annual primary production.

Global carbonate production in the model ranges between 0.4 to $1.1 \mathrm{GT} \mathrm{C} / \mathrm{y}$. It falls within the range of published estimates (Iglesias-Rodriguez et al., 2002). In the model, between 26 to $29 \%$ of the carbonate production is exported at $100 \mathrm{~m}$. The low export flux results from the prescribed routing of carbonate production, where half of the potential production is routed to the sinking particles. Grazing further reduces the sinking carbonate flux by imposing that $50 \%$ of grazed shells will dissolve. The model predicts global deposition, as well as burial fluxes of $\mathrm{CaCO}_{3}$ in line with published estimates.

Global BSi production ranges between 5 to $6 \mathrm{GT}$ Si per year. These numbers are comparable to the recent estimate published by Tréguer (2002). Eighty, respectively $67 \%$ of production is exported at $100 \mathrm{~m}$. These exported fluxes are higher than the 50\% quoted in Tréguer (2002). Similarly, the BSi flux reaching the sediment-water interface is too large (Tréguer, 2002). The model underestimates the dissolution of BSi in the upper ocean and in the deeper water column. As a result, the global burial flux of $\mathrm{BSi}$ is overestimated as well.

According to Seiter et al. (2005) 0.5 GT C/y reach the seafloor below $1000 \mathrm{~m}$ water depth. Model versions PISCESSTD1, STD2 and K\&E yield comparable fluxes with $0.4 \mathrm{GT}$ $\mathrm{C} / \mathrm{y}$ for STD and $0.5 \mathrm{GT} \mathrm{C} / \mathrm{y}$ for K\&E. Computed fluxes are too low for STD3 (0.1 GT C/y), respectively too high for BAL (0.9 GT C/y). Global burial fluxes of POC reported by Seiter et al. (2005) range from 0.002 to $0.12 \mathrm{GT} \mathrm{C} / \mathrm{y}$. With the exception of PISCES-BAL, modeled burial fluxes fall within the range of the independent estimate. Benthic $\mathrm{O}_{2}$ fluxes provide an integrated measure of metabolic activity. Global yearly integrated $\mathrm{O}_{2}$ fluxes computed from the gridded data set of Jahnke (1996) amount to $46.8 \mathrm{Tmol} \mathrm{O}_{2} / \mathrm{y}$. Oxygen fluxes quoted in Table 4 are calculated over the same area as the observations making them directly comparable. 
Table 4. Comparison between global fluxes predicted by the different model versions and independent estimates. Units are in GT carbon (POC and $\left.\mathrm{CaCO}_{3}\right)$, silicon $(\mathrm{BSi})$ and $\mathrm{Tmol} \mathrm{O}_{2}\left(\mathrm{O}_{2}\right.$ fluxes) per year.

\begin{tabular}{|c|c|c|c|c|c|c|}
\hline Model & STD1 & STD2 & STD3 & $K \& E$ & Ballast & Ind. Est. \\
\hline \multicolumn{7}{|c|}{ Global production rates (GT C or Si per y) } \\
\hline $\mathrm{PP}$ & 26 & 28 & 43 & 37 & 21 & $40-60^{(1)}$ \\
\hline $\mathrm{BSi}$ & 5.0 & 5.0 & 5.0 & 5.0 & 6.0 & $6.7^{(3)}$ \\
\hline $\mathrm{CaCO}_{3}$ & 0.7 & 0.8 & 1.2 & 1.1 & 0.4 & $0.72-1.4^{(2)}$ \\
\hline \multicolumn{7}{|c|}{ Global export rates at $100 \mathrm{~m}$ (GT C or Si per y) } \\
\hline POC & 8.0 & 8.0 & 10 & 5.0 & 11 & \\
\hline $\mathrm{BSi}$ & 4.0 & 4.0 & 4.0 & 4.0 & 4.0 & $3.4^{(3)}$ \\
\hline $\mathrm{CaCO}_{3}$ & 0.2 & 0.2 & 0.3 & 0.3 & 0.1 & \\
\hline \multicolumn{7}{|c|}{ Flux at sediment-water interface below 1000 m (GT C or Si per y) } \\
\hline POC & 0.4 & 0.4 & 0.1 & 0.5 & 0.9 & $0.5^{(4)}$ \\
\hline $\mathrm{BSi}$ & 3.0 & 3.0 & 3.0 & 3.0 & 2.0 & $0.8^{(3)}$ \\
\hline $\mathrm{CaCO}_{3}$ & 0.2 & 0.2 & 0.3 & 0.3 & 0.1 & $0.3^{(5)}$ \\
\hline \multicolumn{7}{|c|}{ Global burial fluxes below 1000 m (GT C or Si per y) } \\
\hline POC & 0.17 & 0.17 & 0.08 & 0.19 & 0.40 & $0.002-0.12^{(4)}$ \\
\hline $\mathrm{BSi}$ & 0.40 & 0.42 & 0.33 & 0.41 & 0.12 & $0.17^{(3)}$ \\
\hline $\mathrm{CaCO}_{3}$ & 0.04 & 0.04 & 0.07 & 0.06 & 0.02 & $0.10^{(2)}$ \\
\hline \multicolumn{7}{|c|}{ Global benthic oxygen flux ( $\mathrm{Tmol} \mathrm{O}_{2}$ per y) } \\
\hline $\mathrm{FO}_{2}$ & 22.1 & 22.1 & 3.60 & 26.1 & 43.9 & $46.8^{(7)}$ \\
\hline
\end{tabular}

(1) Carr et al. (2006); (2) Iglesias-Rodriguez et al. (2002); (3) Tréguer (2002); ${ }^{(4)}$ Seiter et al. (2005); (5) flux at $1000 \mathrm{~m}$ after Milliman and Droxler (1996); (6) Jahnke (1996).

Oxygen fluxes predicted by PISCES-BAL are of the same order of magnitude as Jahnke (1996). PISCES-STD1, STD2 and $K \& E$ yield benthic respiration rates a factor two below observations. Model version PISCES-STD3 largely underestimates benthic $\mathrm{O}_{2}$ uptake. For PISCES-STD1, STD2 and $\mathrm{K} \& \mathrm{E}$, particulate organic $\mathrm{C}$ fluxes at $1000 \mathrm{~m}$ are in agreement with independent estimates, while burial fluxes are at the upper end of the latter, and oxygen fluxes are too low. Results of PISCES-BAL provide a contrasting picture with overestimated POC fluxes at 1000, as well as too large burial fluxes, but $\mathrm{O}_{2}$ fluxes in line with Jahnke (1996). This suggests that the model underestimates benthic respiration rates. Increasing the respiration rate will lower the burial flux of POC, while increasing $\mathrm{O}_{2}$ uptake. While model versions PISCES-STD1, STD2 and K\&E are expected to be improved with respect to predicted burial fluxes and benthic $\mathrm{O}_{2}$ consumption, we anticipate an overestimation of $\mathrm{O}_{2}$ fluxes by PISCES-BAL in response to higher respiration rates.

\subsection{Ocean productivity and export}

The biogeochemical model PISCES in its standard version (STD1 to STD3) reproduces to a large degree the observed large-scale distributions of chlorophyll (Fig. 1). The model overestimates the area of the oligotrophic gyres. The same tendency is found in the model versions PISCES-K\&E and PISCES-BAL. In particular in the Northern hemisphere, the transition between the oligotrophic regions and the productive latitudes has a North-South and West-East trend not present in the remote sensing data. This trend in biogeochemical tracer distribution reflects the characteristics of the hydrodynamic forcing fields provided by the model OPA (Madec et al., 1998).

While considerable efforts have been devoted to the quantification of primary production by in situ and satellite based techniques, the link between ocean productivity and particle export is less well understood. The pe-ratio defined as the ratio of particle export to primary production is a useful parameter for integrated marine system analyses. We included it in our study in order to evaluate the skills of the PISCES model to reproduce the underlying large scale biogeochemical processes. In order to compare modeled pe ratios to the data set used in Dunne et al. (2004), we integrated the primary production over, and calculated the POC at the depth of the euphotic zone. 

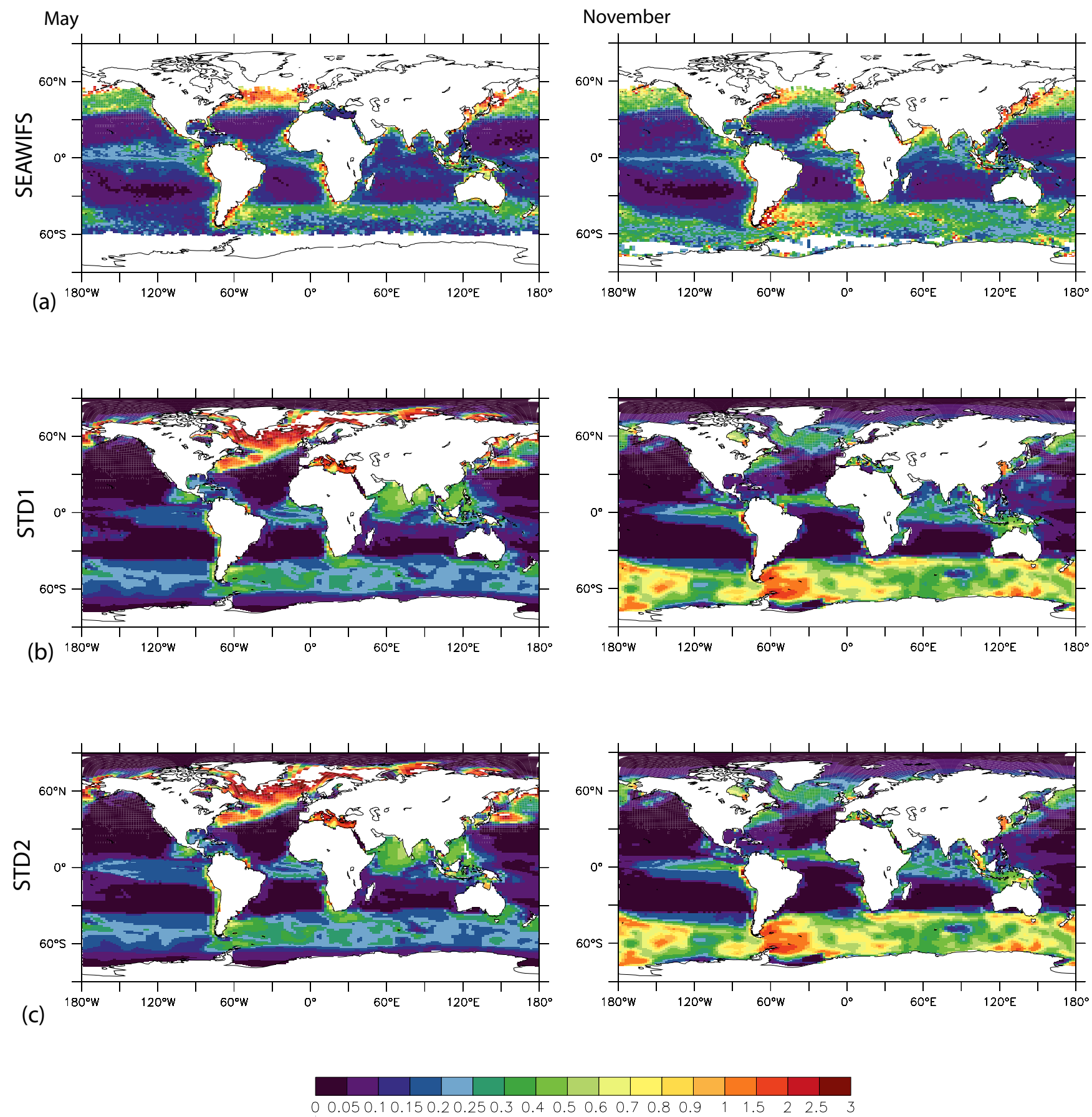

chlorophyll $(\mathrm{mg} / \mathrm{m} 3)$

Fig. 1. Comparison between mean chlorophyll concentrations $\left(\mathrm{mgChl} / \mathrm{m}^{3}\right)$ for May and November from SeaWifs and model output. (a) SeaWifs, (b) PISCES-STD1, (c) PISCES-STD2, (d) PISCES-STD3, (e) PISCES-K\&E, (f) PISCES-BAL.

Modeled pe-ratios are compared to the observed ones in Fig. 2. They are weakly correlated to the observations for PISCES-STD1 (Fig. 2a). The model fails to reproduce the spatial variability present in the data set. In the subpolar and polar regions, data-based pe-ratios range from $<0.1$ to $>0.7$, while model output is confined between 0.2 to $<0.4$. The correlation is improved for PISCES-STD2 and PISCES-STD3, the experiments without aggregation (STD2, Fig. 2b), respectively with a high flux-feeding intensity (STD3, Fig. 2c). In both experiments the partition between small and large 

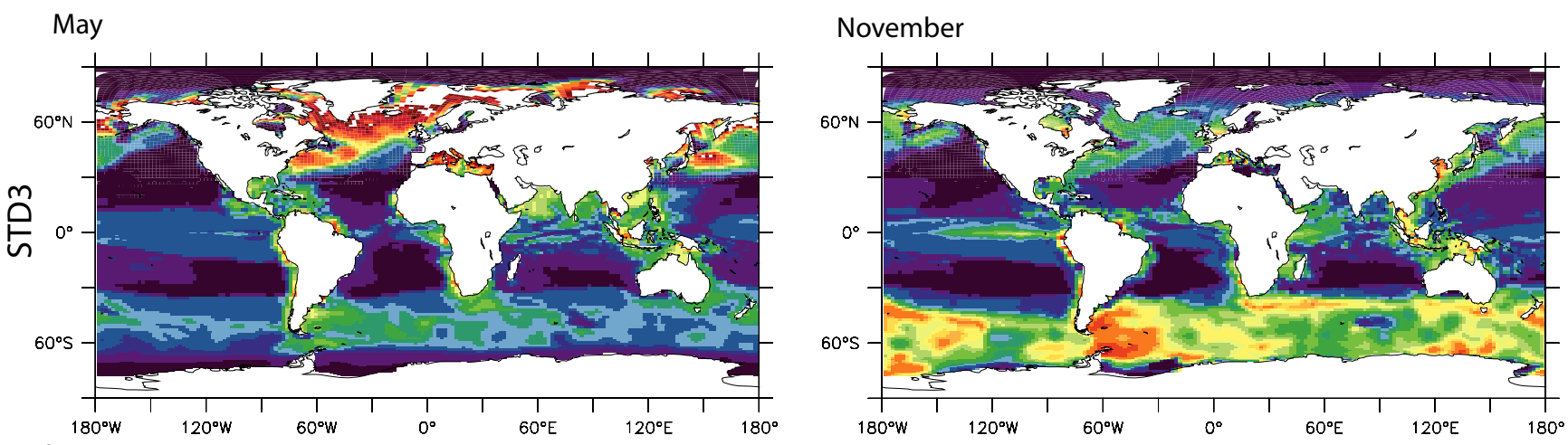

(d)
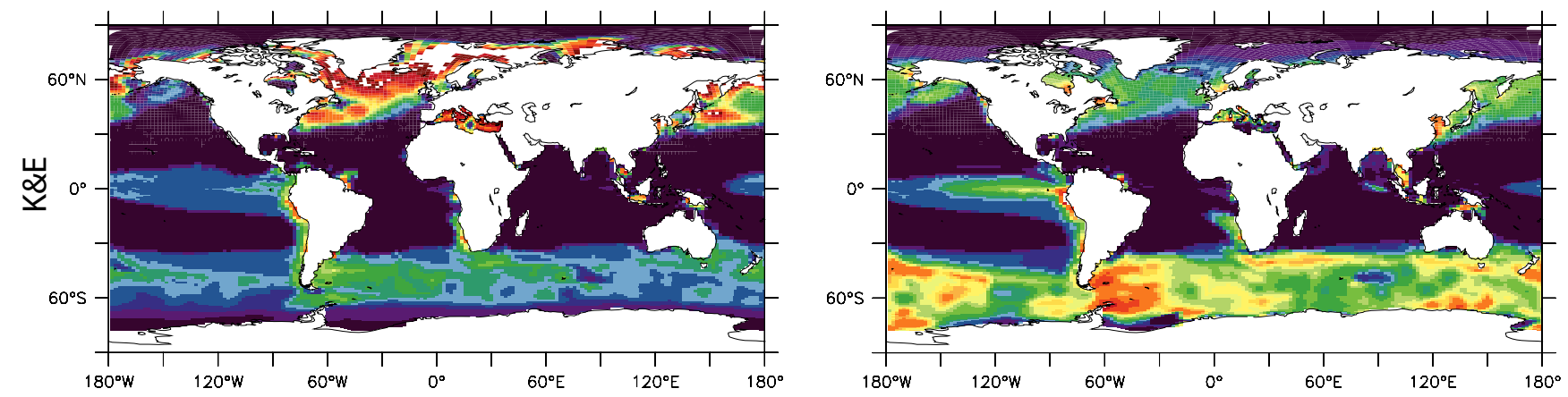

(e)
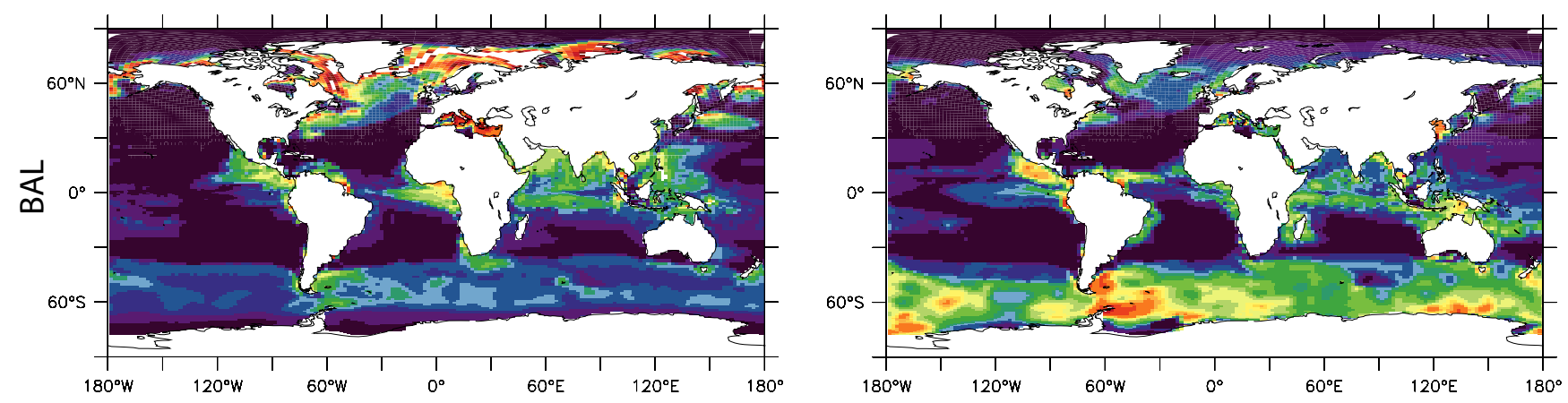

(f)

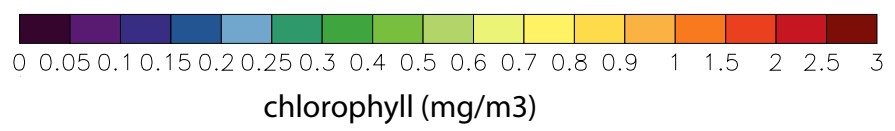

Fig. 1. Continued.

particles is changed in comparison to PISCES-STD1: aggregation shifts mass from small to large particles (STD2), flux feeding consumes large particles (STD3). This will affect the mean sinking speed and ultimately the flux. This effect is however small and the scatter plots of Fig. 2 suggest no significant difference between the three simulations.
The implementation of a parameterization of the particle size-spectrum and the associated prognostic sinking speed (PISCES-K\&E) clearly improves the fit between model output and data (Fig. 2d). The spatial variability of observed peratios is better reproduced. There is no systematic regional bias. Including a full particle size spectrum to the model is 



Fig. 2. Comparison of pe-ratios computed by the model and the data synthesis of Dunne et al. (2005). (a) PISCES-STD1, (b) PISCESSTD2, (c) PISCES-STD3, (d) PISCES-K\&E, (e) PISCES-BAL.

essential for the satisfying reproduction of pe-ratios by the model. To the contrary, model output and observation are anti-correlated (negative $r$ ) in the case of PISCES-BAL. The model largely overestimates the variability of pe-ratios in the tropics, while underestimation it in the subpolar and polar regions.

\subsection{Particulate organic carbon fluxes below $1000 \mathrm{~m}$}

The comparison between sediment trap data and model derived POC fluxes is displayed on Fig. 3. The model version PISCES-STD1 predicts a wider spread in POC fluxes between 1000 and $2000 \mathrm{~m}$ than present in the data set with a tendency towards overestimation. Modeled deep water fluxes are of the right order of magnitude. Their variability below $3800 \mathrm{~m}$ is underestimated by the model. POC fluxes across the water column (Fig. 3b) predicted by PISCES STD2 are strikingly similar to the reference version STD1. The same holds for the mean sinking speed (Fig. 8a). Both model versions differ with respect to aggregation-disaggregation which is not represented in STD2. The lack of differences between both versions suggests that processes of aggregation and disaggregation are only of second order importance in controlling yearly averaged fluxes of POC across the water column in the standard model formulation.

The impact of flux feeding intensity on mid- and deepwater POC fluxes is shown in Fig. 3c. Modeled POC fluxes correspond to trap data over the 1000 to $2000 \mathrm{~m}$ depth range. Deep water fluxes are, however, largely underestimated by the model with values below $10 \mathrm{mmolC} / \mathrm{m}^{2} / \mathrm{y}$. Increasing flux feeding intensity in PISCES-STD3 deteriorates the representation of deepwater POC fluxes. Flux feeding impacts the flux of big POC particles. Increasing flux feeding in the model standard version, decreases the flux of fast sinking $\mathrm{POC}_{b}$ and thereby lowers the average sinking speed (Fig. 8a). It translates into a more intense POC recycling in the mesopelagos and thus an overall shallower penetration of POC in the water column.

The comparison between modeled POC fluxes and our data base, suggests that updating the standard version of PISCES to take into account the particle size spectrum and a prognostic sinking speed (PISCES-K\&E, Fig. 3d) does not significantly improve the fit of model output to data compared to the reference version PISCES-STD1 (Fig. 3a). The correspondence between modeled POC fluxes and trap data is slightly improved in PISCES-BAL (Fig. 3e). Similar to model versions PISCES-STD1 and PISCES-K\&E, the model overestimates fluxes between 1000 and $2000 \mathrm{~m}$. They are of the right order of magnitude below $2000 \mathrm{~m}$.

The tendency of the model to overestimate POC fluxes between roughly 1000 and $3000 \mathrm{~m}$ is present in all model versions, but PISCES-STD3. An evaluation of trapping efficiency of sediment traps (Yu et al., 2001) suggests a low and erratic efficiency in the mesopelagic. This is also confirmed by a comparison between sediment trap data and inverse modeling results (Usbeck et al., 2003). The low trapping efficiency of sediment traps at mid-depth might explain the systematic off-set between modeled fluxes and trap results. On the other hand, the overestimation of POC fluxes at mid depth by the model goes along with an underestimation below $3000 \mathrm{~m}$. While it is true that trap data carry large uncertainties, the systematic bias of the evolution of POC fluxes with depth predicted by the PISCES suggests that essential controlling processes or not or badly represented in the model.

\subsection{Surface sediment composition and benthic oxygen de-} mand

Material fluxes are integrated to surface sediments, where the oxidation of organic $\mathrm{C}$ is the major driving force of early diagenetic reactions. In the model experiment, the 

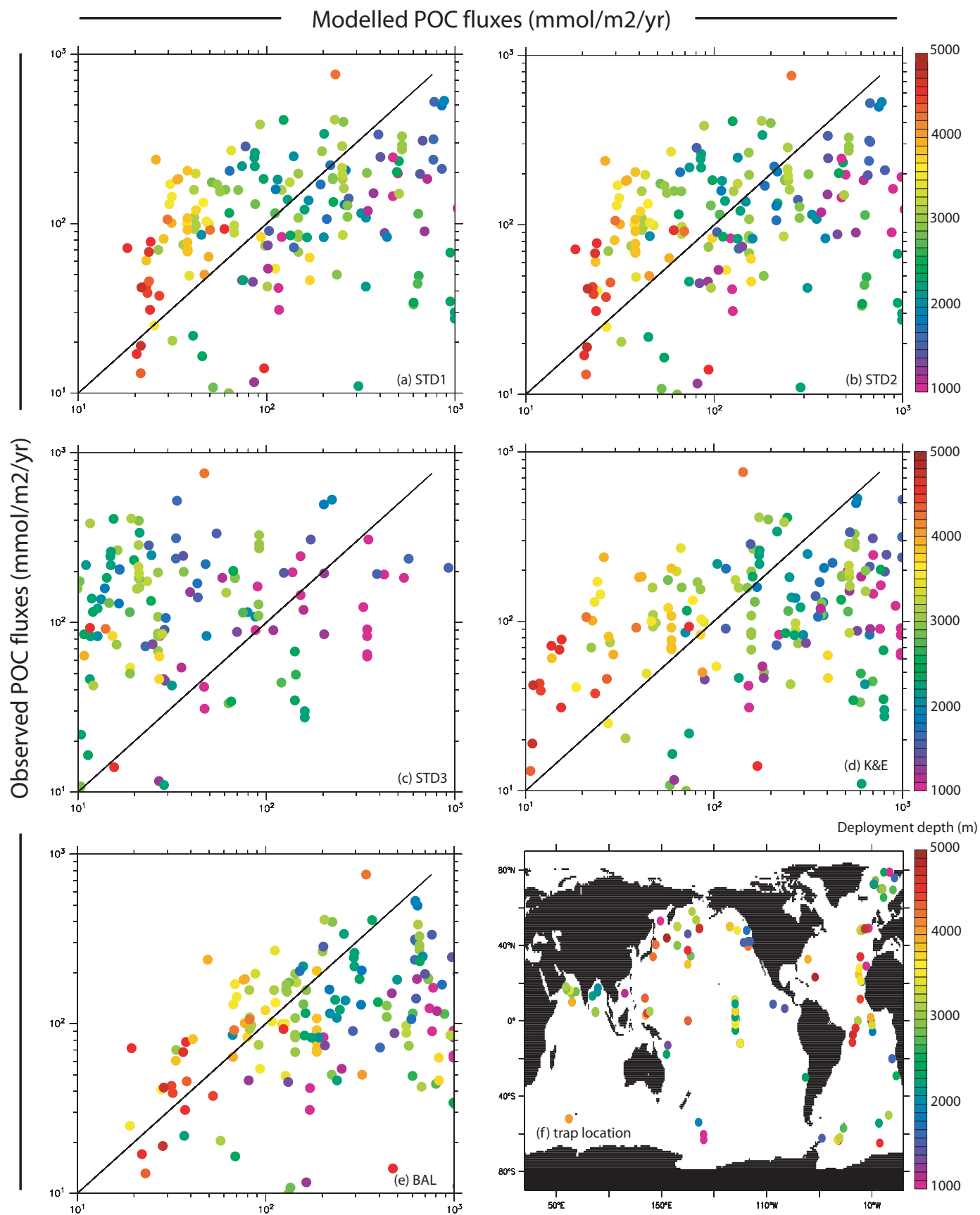

Fig. 3. Comparison between POC fluxes $\left(\mathrm{mol} \mathrm{C} / \mathrm{m}^{2} / \mathrm{y}\right)$ estimated from sediment traps and modeled fluxes. The color code corresponds to the depth of deployment of sediment traps. Values $<10 \mathrm{mmol} \mathrm{C} / \mathrm{m}^{2} / \mathrm{y}$ are excluded from the graph.

sediment composition was obtained by forcing the sediment with yearly averaged particle fluxes and bottom water concentrations. The resulting distributions of $\mathrm{BSi}, \mathrm{CaCO}_{3}$ and POC are compared to observations in Fig. 4 for PISCESSTD1. Model results are averaged over the first $\mathrm{cm}$ of sediment $(0-1 \mathrm{~cm})$. The model predicts POC levels between 1 and $2 \%$ per sediment dry weight in large areas of open ocean sediments (Fig. 4a). Unrealistic high levels of POC are com- puted over continental margins, for the northern North Atlantic and part of the Arctic Ocean. Data coverage (Fig. 4b) is sparse and concentrated in the Atlantic and Arctic basins. Observed POC levels up to $1 \%$ sediment dry weight are reported for Atlantic open ocean sediments. Considering the uncertainty associated to POC data of surface sediments, the comparison between modeled and observed POC levels is judged satisfying for open ocean sediments excluding the 
PISCES-STD1
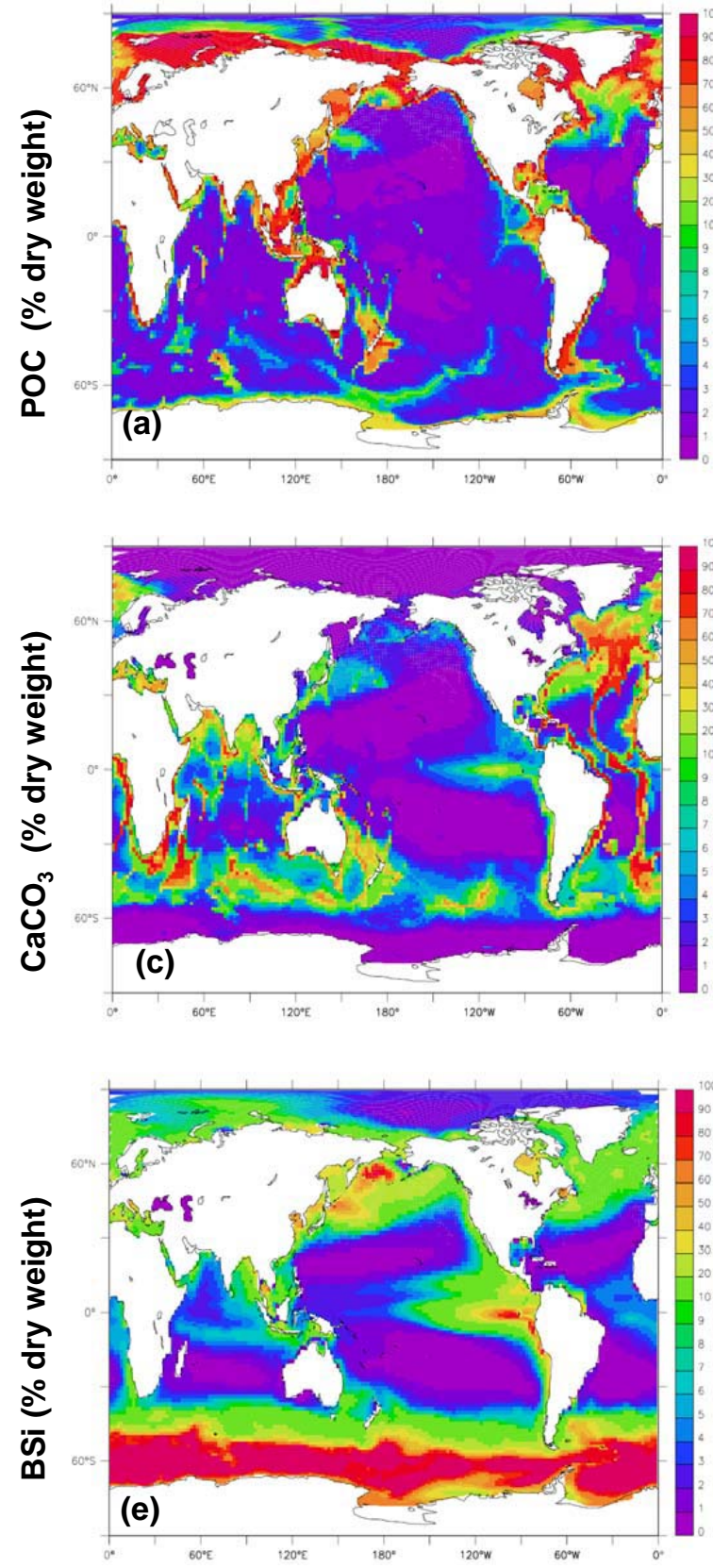

Data
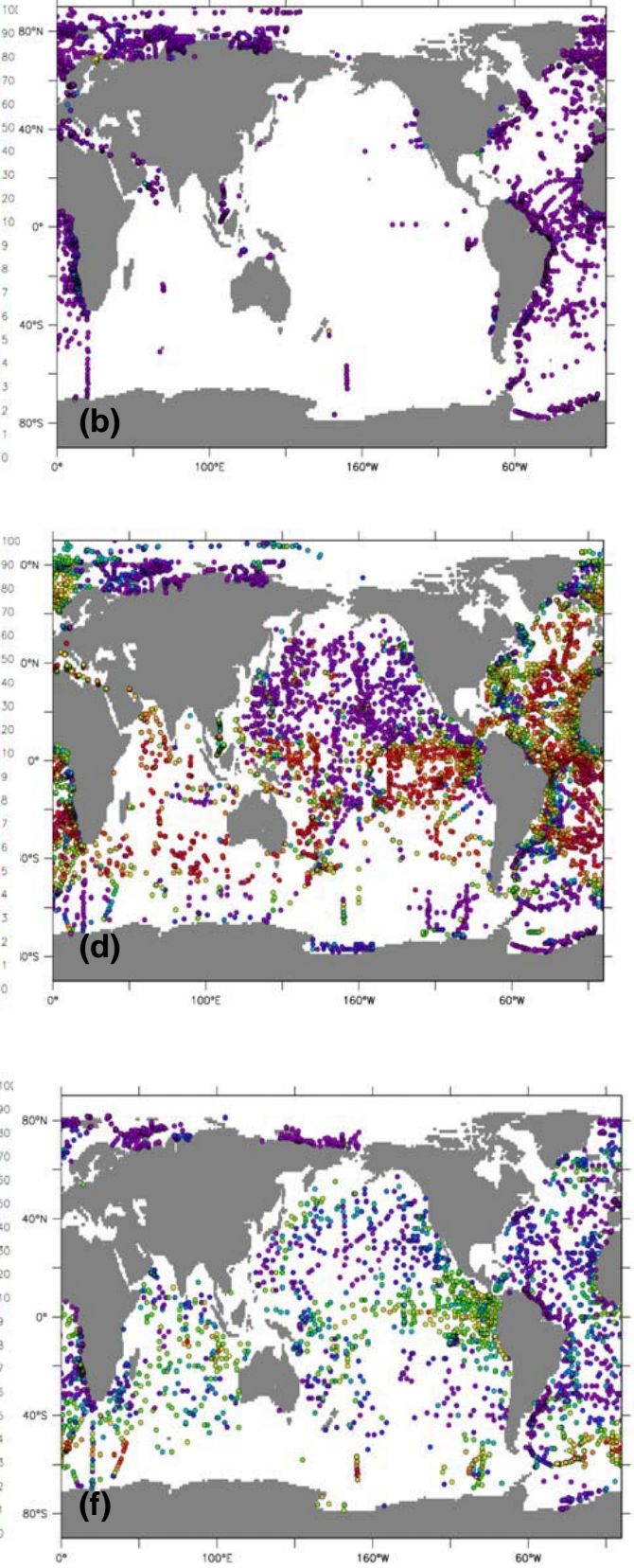

Fig. 4. Modelled and observed bulk composition (\%-dry weight) of surface sediments: $\mathrm{POC}, \mathrm{CaCO}_{3}$, BSi. Model output corresponds to the mean composition of the top first $\mathrm{cm}$ computed for PISCES-STD1. Data reported for the same depth interval $(0-1 \mathrm{~cm})$ are plotted as dots. Model output and data are on the same colour scale.

high POC areas mentioned above. The misfit between model and data in areas with seasonal ice cover, respectively continental margins in part reflects the fact that model does not fully resolve the corresponding characteristic dominant physical and biogeochemical processes. While the high POC levels in northern North Atlantic pelagic sediments follow surface ocean productivity (Fig. 1b), their magnitude is unrealistic and can at present not be explained.
Simulated distributions of the average percentage of $\mathrm{CaCO}_{3}$ (Fig. 4c) and BSi (Fig. 4e) in the top cm of surface sediments agree with respect to order of magnitude and large scale pattern with observations $\left(\mathrm{CaCO}_{3}\right.$, Fig. $4 \mathrm{~d}$; $\mathrm{BSi}$, Fig. 4f). The modeled distribution of $\mathrm{CaCO}_{3}$ reflects the effect of bathymetry on $\mathrm{CaCO}_{3}$ preservation with high values along topographic heights (e.g. the Mid Ocean Ridge in the Atlantic basin). The BSi content of surface sediments reflects 
surface ocean the diatom productivity: e.g. high values in the Pacific Equatorial upwelling region, low values in the oligotrophic gyres, BSi-rich belt centered at $60^{\circ}$ South.

Model output is evaluated statistically for $\mathrm{BSi}$ and $\mathrm{CaCO}_{3}$ by subsampling the model at the locations of the data base. Measured and simulated sediment compositions are compared for the top first $\mathrm{cm}$ of sediment. For each model version the standard deviation and the correlation coefficient (r) are calculated. The standard deviation of model output is normalized with respect to the data. Statistics are summarized on the Taylor diagram (Taylor, 2001) given in Fig. 5. The correlation between model output and data is intermediate $(0.55<\mathrm{r}<0.60, \mathrm{BSi}$, PISCES-STD and K\&E) to weak $\left(0.5<\mathrm{r}, \mathrm{CaCO}_{3}\right.$, all model versions; BSi, PISCES-BAL). The normalized standard deviation greater than 1 for BSi suggests that the model in general overestimates of the variability BSi levels. This is consistent with an overestimation of latitudinal gradients in BSi in particular in the Southern Ocean and across the Eastern Pacific Equatorial upwellinng. The PISCES-BAL simulation is a noteworthy exception, but it has a weaker correlation coefficient than the other model versions. The modeled $\mathrm{CaCO}_{3}$ composition correlates weakly to data. The normalized standard deviation suggests an underestimation of spatial gradients. The comparison of different model versions does not reveal significant differences.

The benthic $\mathrm{O}_{2}$ fluxes provide an integrated measurement of the metabolic activity of surface sediments. Figure 6 presents the comparison between the data based estimate by Jahnke (1996) (Fig. 6a) and model output for STD1 (Fig. 6b). While PISCES-STD1 reproduces the spatial distribution of $\mathrm{O}_{2}$ fluxes, it underestimates its absolute value in sediments overlain by productive waters. This is consistent with an integrated flux (Table 4) roughly $50 \%$ of that calculated from Jahnke (1996).

Benthic $\mathrm{O}_{2}$ fluxes predicted by different model versions are compared with respect to normalized standard deviation and correlation to Jahnke (1996) in Fig. 6c. All model versions, but PISCES-STD3 predict a belt of high $\mathrm{O}_{2}$ between $60^{\circ} \mathrm{S}$ and $40^{\circ} \mathrm{S}$. We computed the corresponding statistics for two latitudinal bands: $60^{\circ} \mathrm{S}$ to $40^{\circ} \mathrm{S}$ and $40^{\circ} \mathrm{S}$ to $60^{\circ} \mathrm{N}$. While in the Southern Ocean, model output and data are not significantly correlated, the correlation is weak from $40^{\circ} \mathrm{S}$ northwards to $60^{\circ} \mathrm{N}$. PISCES-BAL yields an integrated $\mathrm{O}_{2}$ flux of $43.9 \mathrm{Tmol} \mathrm{O}_{2} / y$ closely corresponding 46.8 Tmol $\mathrm{O}_{2} / \mathrm{y}$ computed for the data base estimate (Table 4). However, based on the statistical criteria plotted in Fig. 6c PISCES-BAL is not superior to the other model versions. The Southern Ocean latitudinal gradient across areas of low and high $\mathrm{O}_{2}$ fluxes is overestimated by the model. Model version PISCES-STD3 stands out with the lowest normalized standard deviation $(<0.4)$ and correlation coefficient for the area northward of $40^{\circ} \mathrm{S}$. This and the underestimation of the integrated $\mathrm{O}_{2}$ flux by an order of magnitude suggest a starving of the benthos due to insufficient delivery of POC to the sediment water interface. Neither the spatial pattern nor

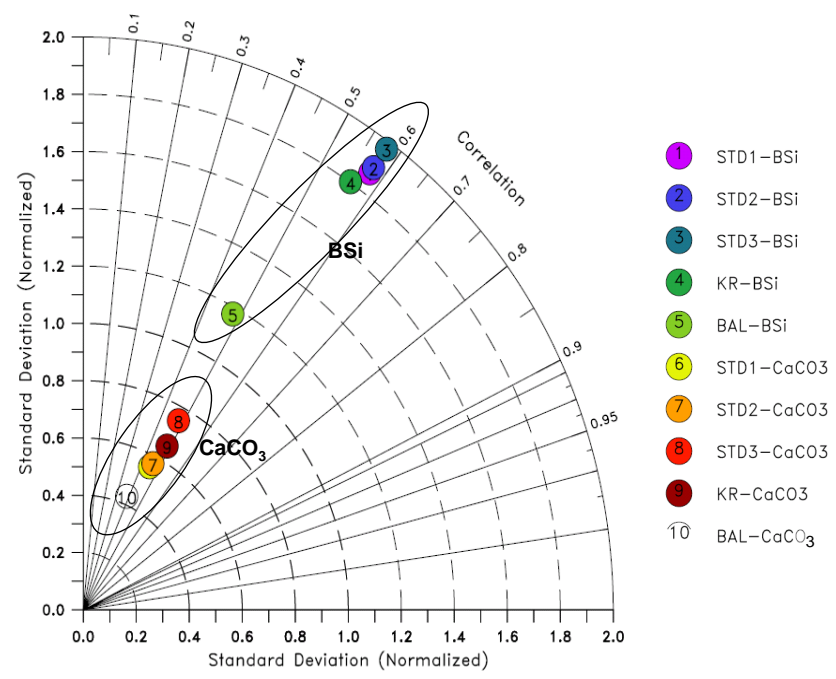

Fig. 5. Taylor diagram comparing modelled distributions of BSi and $\mathrm{CaCO}_{3}$ in the top first $\mathrm{cm}$ of sediments for all 5 experiments. Model output is subsampled at the location of observations. Model standard deviation is normalized to the data. Symbols for PISCESSTD1 and STD2 are superposed.

the intensity of $\mathrm{O}_{2}$ fluxes present in the large scale distribution of Jahnke (1996) is reproduced by PISCES-STD3.

\subsection{Representing pelagic-benthic coupling in a global bio- geochemical ocean model}

Model experiments were set-up in order to isolate the effect of different particle flux parameterization on POC fluxes across the water column, while keeping the effect on the distribution of dissolved properties minimal. Changes in ocean productivity (Table 4 and Fig. 1) suggest the reorganization of nutrient fields in the upper ocean in response to particle flux parameterizations. While these changes are a transient feature, their analysis provides insight in the coupling between surface ocean productivity and particle export. This is illustrated in Fig. 7 by the changes in nitrate concentration between the reference simulation PISCES-STD1 and experiments STD3 (Figs. 7a, b), K\&E (Figs. 7c, d) and BAL (Figs. 7e, f). Model version STD2 is not included since it is close to identical to STD1. To complete the analysis, we present global mean sinking speed (Fig. 8a) and global mean POC fluxes (Fig. 8b) as a function of depth.

The increase in global primary production (Table 4) between model versions STD1 and STD3 from 26 to 43 GT $\mathrm{C} / \mathrm{y}$ is consistent with an enrichment of mid-waters in $\mathrm{NO}_{3}$. The latter is due to the shallower depth penetration (e.g. efolding depth of average POC fluxes) of POC fluxes in STD3 (667 m) compared to STD1 (1000 m). For comparison, Andersson et al. (2004) derive an e-folding depth of $1333 \mathrm{~m}$ for POC fluxes based on sediment consumption measurements. Both model versions differ solely with respect to the intensity 

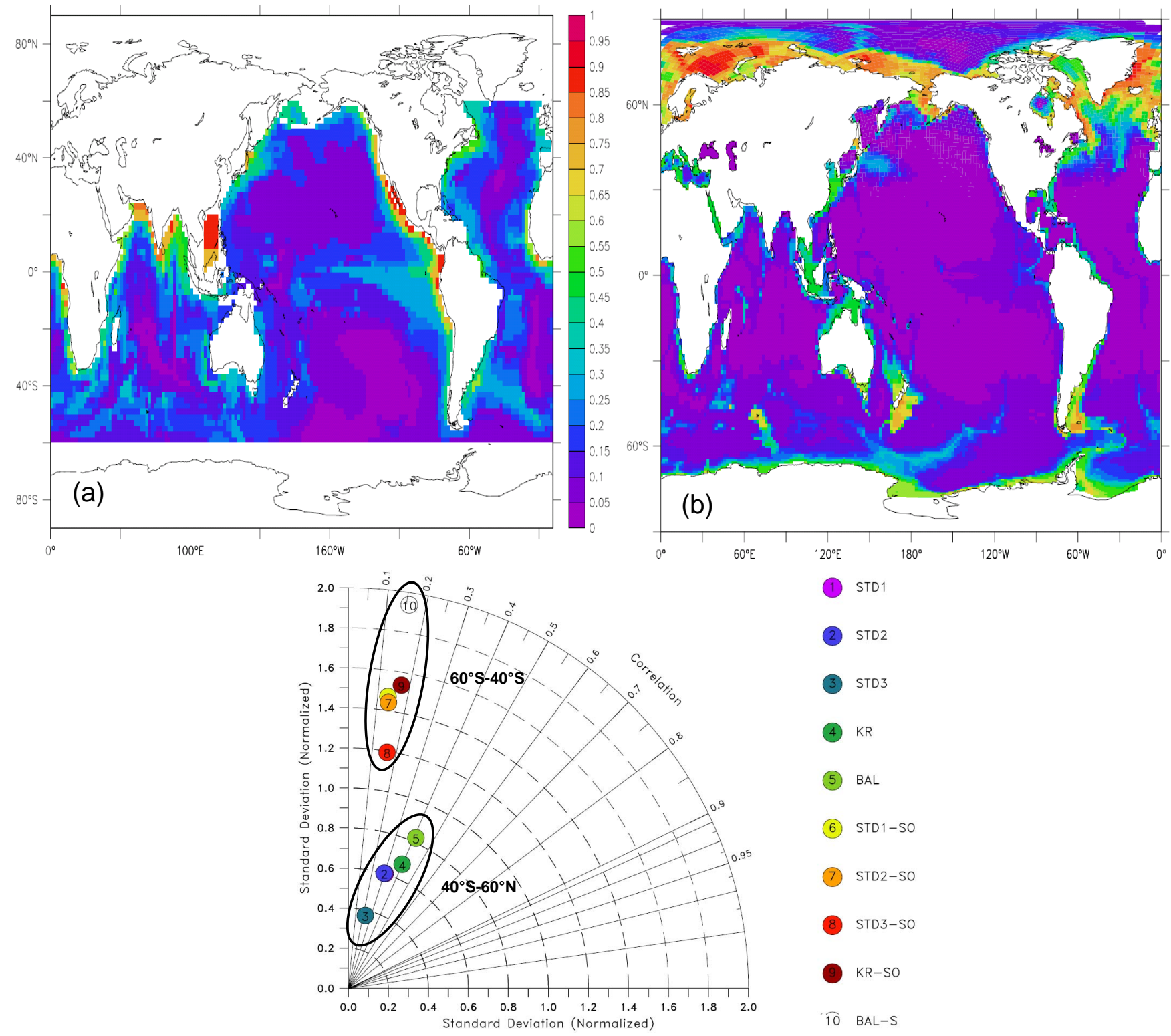

(1) STD1

(2) STD2

(3) STD3

(4) $\mathrm{KR}$

(5) BAL

(6) STD1-SO

(7) STD2-SO

8 STD3-SO

(9R-SO

TO BAL-S

(c)

Fig. 6. Oxygen fluxes $\left(\mathrm{mol} / \mathrm{m}^{2} / \mathrm{y}\right)$ at the sediment water interface: (a) independent estimate by Jahnke (1996); (b) fluxes computed by PISCES-STD1, (c) Taylor diagram comparing modelled distributions of $\mathrm{O}_{2}$ fluxes. Model standard deviation is normalized to data. Two regions are distinguished: between $60^{\circ} \mathrm{S}$ and $40^{\circ} \mathrm{S}$ (label SO) and North of $40^{\circ} \mathrm{S}$. Symbols for PISCES-STD1 and STD2 are superposed.

of flux feeding. The latter is twice as high in STD3. Increasing the flux feeding intensity deteriorates the representation of deepwater POC fluxes (Figs. 3 and 8a) and leads to a starving of the benthos (Table $4, \mathrm{O}_{2}$ fluxes). Flux feeding impacts the flux of large POC particles. Increasing flux feeding in the model standard version, decreases the flux of fast sinking $\mathrm{POC}_{b}$ and thereby lowers the average sinking speed (Fig. 8b) at mid-depth. It translates into a more intense POC recycling in the mesopelagos and thus an overall shallower penetra- tion of POC in the water column. This fuels the productivity (Fig. 1) at the boundary, as well as in the oligotrophic gyres, giving rise in turn to a higher POC flux at $100 \mathrm{~m}$. Our results corroborate previous studies reporting the importance of flux feeding as a control on mesopelagic POC fluxes (Stemmann et al., 2004a, b).

The global yearly primary production computed for PISCES-K\&E of $37 \mathrm{GT} \mathrm{C} / \mathrm{y}$ is intermediate to the STD1 and STD3 (Table 1). This model version includes a 

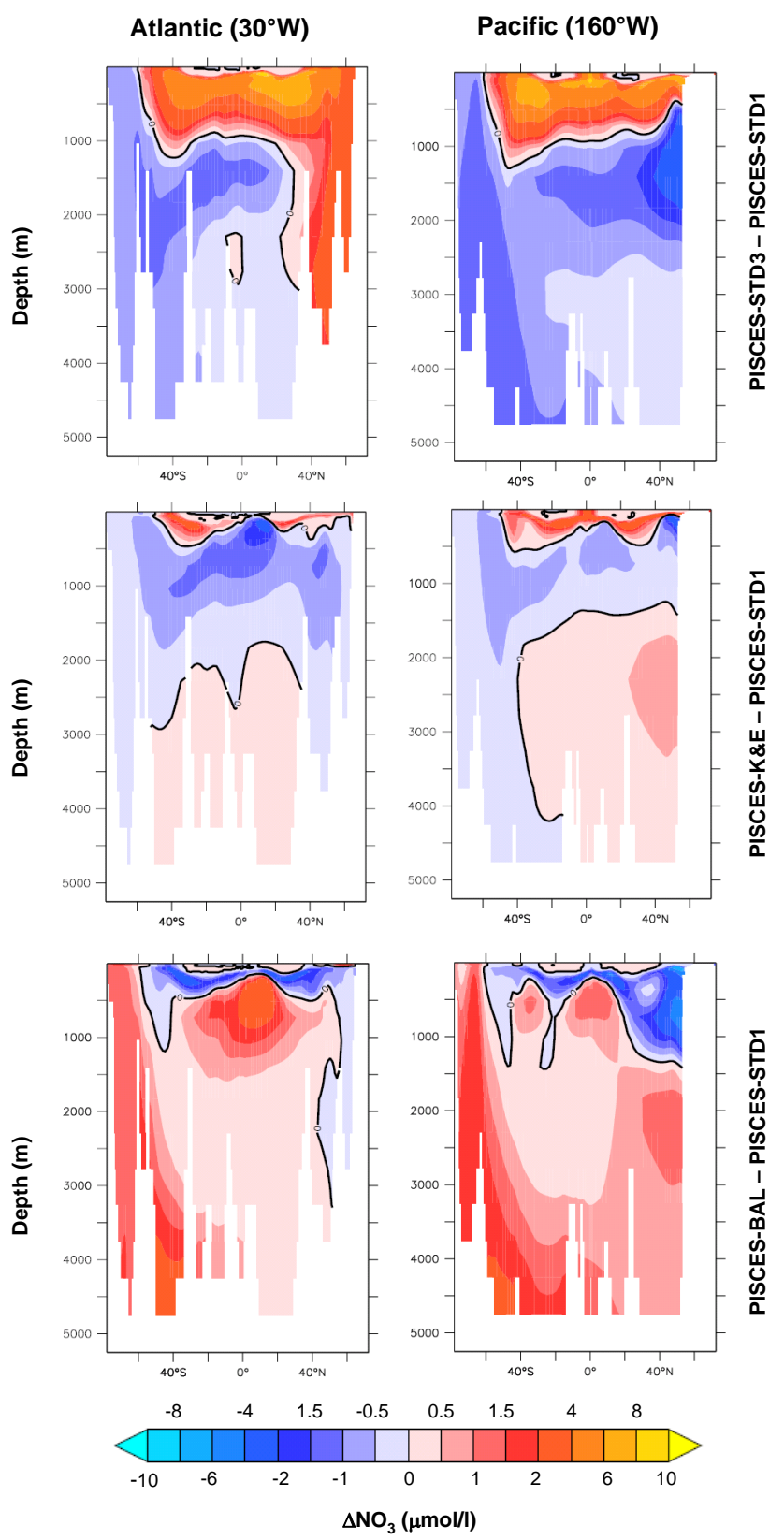

Fig. 7. Changes in $\mathrm{NO}_{3}$ concentrations $(\mu \mathrm{mol} / \mathrm{l})$ after 100 years of integration relative to the reference version PISCES-STD1. Left: Atlantic basin; Right: Pacific basin.

parameterization of a full particle size spectrum and prognostic sinking speed. Differences in $\mathrm{NO}_{3}$ levels are small, suggesting a tendency towards higher, respectively lower concentration rather than a significant change. Slightly higher $\mathrm{NO}_{3}$ levels are confined to a narrow depth interval (Figs. 7c, d). Below $500 \mathrm{~m}$, the $\mathrm{NO}_{3}$ concentration is slightly lower. The depth penetration of POC fluxes is $1111 \mathrm{~m}$ and thus comparable to STD1. Differences between the two model versions become apparent in Fig. 8. The depth evolution of

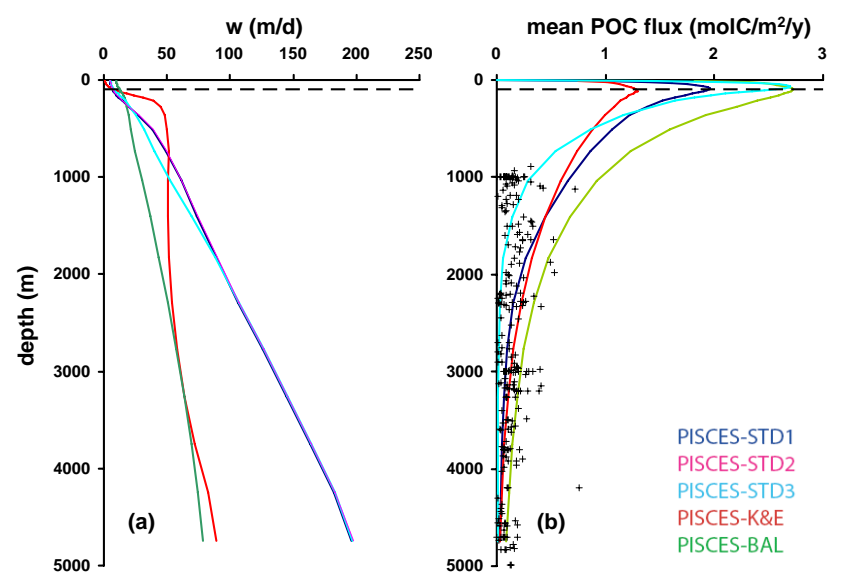

Fig. 8. (a) Global mean sinking speed (m/d) as a function of depth of water column predicted by different model versions. (b) Global mean POC fluxes $\left(\mathrm{mol} \mathrm{C} / \mathrm{m}^{2} / \mathrm{y}\right)$ as a function of depth of water column.

sinking speed (Fig. 8a) in PISCES-K\&E reveals values below $3 \mathrm{~m} / \mathrm{d}$ down to $100 \mathrm{~m}$, followed by a rapid increase up to $50 \mathrm{~m} / \mathrm{d}$ between 100 and $500 \mathrm{~m}$. The strong increase in sinking speed occurs at the base of the mixed layer where high concentration of particles and high turbulence promote particle coagulation. The low sinking speeds at shallow depth implies a longer particle residence time and enhanced recycling. Both translate into higher $\mathrm{NO}_{3}$ levels, especially at the latitude of oligotrophic gyres. Below this depth, aggregation promotes higher sinking speeds and particles are rapidly exported to greater depth (Fig. 8b). Particulate organic C fluxes peak around $100 \mathrm{~m}$ in all model versions, but maximum fluxes are lowest for $\mathrm{K} \& \mathrm{E}$. Consistent with the greater penetration depth of POC flux, its decrease with depth is less pronounced in PISCES-K\&E. This explains the tendency towards lower $\mathrm{NO}_{3}$ levels below $500 \mathrm{~m}$ in this model version.

The comparison between $\mathrm{NO}_{3}$ levels between PISCESSTD1 and PISCES-BAL (Figs. 7e, f) reveals large changes. Particulate organic $\mathrm{C}$ fluxes are highest in PISCES-BAL (Fig. 8b). An e-folding depth of $1250 \mathrm{~m}$ was computed from the mean global POC profile. In this model version a large fraction of POC is transferred to greater depth. Nutrients are transferred from shallow to mid-depth, leading to an impoverishment for surface waters over large areas. This in turn explains the low global yearly rate of primary production of $21 \mathrm{GT} \mathrm{C} / \mathrm{y}$.

\section{Conclusion}

The discussion highlights the difficulties in reconciling surface ocean observations, mid- to deep-water particle fluxes and sediment data. At the present stage, the model is unable to reproduce the strong initial decrease in POC and the close the constant flux at great depth (Fig. 8b). Model version 
PISCES-STD3 simulates a rapid loss of POC flux at shallow depth. The penetration depth of POC is however too shallow and the deeper water column and the benthos are starved. To the contrary, PISCES-BAL delivers greater amounts of POC to the sediment water interface, while overestimating POC fluxes at mid-depth. This study suggests that different processes control POC fluxes at different depths.

In order to capture the link between surface ocean productivity and POC export at the base of the euphotic zone, a prognostic sinking speed computed from the continuous particle size spectrum (PISCES-K\&E) is essential (Fig. 2). Particle coagulation driven by turbulence in the wind mixed layer and associated changes in particle size spectrum and thus sinking speed appears as a key process in controlling pe-ratios. The fit between modeled pe-ratios and observations yielded by PISCES-STD, K\&E and BAL is significantly different. In terms of its capability for reproducing the observed variability of pe-ratios across different oceanic regimes, PISCES-K\&E is superior to the two other parameterizations.

The fate of POC fluxes leaving the well-mixed surface ocean is most sensitive to the intensity of zooplankton flux feeding and thus to the composition of the zooplankton community. All model parameters being kept constant and for a given intensity of flux feeding, the capability of the model to reproduce yearly averaged POC fluxes below $1000 \mathrm{~m}$ and benthic oxygen demand does in first order not dependent on the resolution of the particle size spectrum. Model results obtained with the PISCES standard version PISCES-STD1 ( 2 particle size classes and sinking speed prescribed for each size class) and with PISCES-K\&E (particle size spectrum and prognostic sinking speed) are similar.

While our model study does not allow to conclusively identify whether particle aggregation or mineral ballasting is the key mechanism controlling POC fluxes in the ocean interior (Passow, 2004), it suggests that aggregate formation is essential to initiate an intense biological pump. High particle fluxes down to the bathypelagos are most likely the result of the combined effect of aggregate formation and mineral ballasting (Passow and DeLaRocha, 2006).

Acknowledgements. This work was supported through grants EVK2-CT-2001-00100 (EU FP5 RTD project ORFOIS) and GOCE-511176 (EU FP6 RTP project CARBOOCEAN) by the European Commission and by the French national program PROOF/OCEVAR. We acknowledge the constructive comments by J. Sarmiento, G. Jackson and an anonymous reviewer. We thank B. Schneider for her help. This is publication number \#2402 from LSCE and No. A 148 from the Bjerkness Centre for Climate Research.

Edited by: J. Middelburg

\section{References}

Alldredge, A. L. and Gotschalk, G.: In situ settling behaviour of marine snow, Limnol. Oceanogr., 33, 339-351, 1988.

Andersson, J. H., Wijsman, J. W. M., Herman, P. M. J., Middelburg, J. J., Soetaert, K., and Heip, C.: Respiration patterns in the deep ocean. Geophys. Res. Lett., 31, L03304, doi:10.1029/2003GL018756, 2004.

Armstrong, R. A., Lee, C., Hedges, J. I., Honjo, S., and Wakeham, S. G.: A new, mechanistic model for organic carbon fluxes in the ocean based on the quantitative association of POC with ballast minerals, Deep Sea Res. I, 49, 219-236, 2002.

Aumont, O., Maier-Reimer, E., Monfray, P., Blain, S., and Pondaven, P.: An ecosystem model of the global ocean including Fe, Si, P co-limitations. Global Biogeochem. Cycles, 17(2), 1060, doi:10.1029/2001GB001745, 2003.

Aumont, O. and Bopp, L.: Globalizing results from ocean in situ iron fertilization studies, Global Biogeochem. Cycles, 20, GB2017, doi:10.1029/2005GB002591, 2006.

Berelson, W. M.: Particle settling rates increase with depth in the ocean. Deep Sea Res. II, 49, 237-251, 2002.

Betzer, P. R., Showers, W. J., Laws, E. A., Winn, C. D., DiTullio, G. R., and Kroopnick, P. M.: Primary productivity and particle fluxes on a transect of the equator at $153^{\circ} \mathrm{W}$ in the Pacific Ocean, Deep Sea Res., 31, 1-11, 1984.

Bopp, L., Kohfeld, K. E., Le Quéré, C., and Aumont, O.: Dust impact on marine biota and atmospheric $\mathrm{CO}_{2}$ during glacial periods, Paleoceanogr., 18, 1046, doi:10.1029/2002PA000810, 2003.

Bopp, L., Aumont, O., Cadule, P., Alvain, S., and Gehlen, M.: Response of diatoms distribution to global warming and potential implications: A global model study, Geophys. Res. Lett., 32, L19606, doi:10.1029/2005GL023653, 2005.

Carr, M.-E., Friedrich, M. A. M., Schmeltz, M., Aita, M. N., Antoine, D., Arrigo, K. R., Asanuma, I., Aumont, O., Barber, R., Behrenfeld, M., Bidigare, R., Buitenhuis, E. T., Campbell, J., Ciotti, A., Dierssen, H., Dowell, M., Dunne, J., Esaias, W., Gentili, B., Gregg, W., Groom, St., Hoepffner, N., Ishizaka, J., Kameda, T., Le Quéré, C., Lohrenz, St., Marra, J., Mélin, F., Moore, K., Morel, A., Reddy, T. E., Ryan, J., Scardi, M., Smyth, T., Turpie, K., Tilstone, G., Waters, K., and Yamanaka, Y.: A comparison of global estimates of marine primary production from ocean color, Deep-Sea Res., 53, 741-770, 2006.

Dittert, N., Corrin, L., Bakker, D., Bendtsen, J., Gehlen, M., Heinze, C., Maier-Reimer, E., Michalopoulos, P., Soetaert, K. E. R., and Tol, R. J. S.: Integrated Data Sets of the FP5 Research Project ORFOIS: Origin and fate of biogenic particle fluxes in the ocean and their interactions with atmospheric $\mathrm{CO}_{2}$ concentrations as well as the amrine sediment (Vol. 1), WDC-MARE Reports 0002, 2005.

Dunne, J. P., Armstrong, R. A., Gnanadesikan, A., and Sarmiento, J. L.: Empirical and mechanistic models for the particle export ratio, Biogeochem. Cycles., 19, GB4026, doi:10.1029/2004GB002390, 2005.

François, R., Honjo, S., Krishfield, R., and Manganini, S.: Factors controlling the flux of organic carbon to the bathypelagic zone of the ocean, Global Biogeochem. Cycles, 16, 1087, doi:10.1029/2001GB001722, 2002.

Heinze, C., Maier-Reimer, E., Winguth, A. M. E., and Archer, D.: A global oceanic sediment model for long-term climate studies, Global Biogeochem. Cycles, 13, 221-250, 1999. 
Iglesias-Rodriguez, M. D., Armstrong, R., Feely, R., Hood, R., Kleypas, J., Milliman, J. D., Sabine, C., and Sarmiento, J.: Progress made in study of ocean's calcium carbonate budget, Eos Trans. AGU, 83, 365, 2002.

Jackson, G. A.: A model for the formation of marine algal flocs by physical coagulation processes, Deep Sea Res., 37, 1197-1211, 1990.

Jackson, G. A.: Flux feeding as a mechanism for zooplankton grazing and its implications for vertical particulate flux, Limnol. and Oceanogr., 38, 1328-1331, 1993.

Jahnke, R. A.: The global flux of particulate organic carbon: Areal distribution and magnitude, Global Biogeochem. Cycles, 10, 7188, 1996.

Klaas, C. and Archer, D. E.: Association of sinking organic matter with various types of mineral ballast in the deep sea: Implications for the rain ratio, Global Biogeochem. Cycles, 16, 116, doi:10.1029/2001GB001765, 2002.

Kriest, I.: Different parameterizations of marine snow in a 1Dmodel and their influence on representation of marine snow, nitrogen budget and sedimentation, Deep Sea Res., 49, 2133-2162, 2004.

Kriest, I. and Evans, G. T.: Representing phytoplankton aggregates in biogeochemical models, Deep Sea Res. I, 46, 1841-1859, 1999.

Kriest, I. and Evans, G. T.: A vertically resolved model for phytoplankton aggregation, Proc. Indian Acad. Sci. Earth Planet. Sci., 109, 453-469, 2000.

Le Quéré, C., Harrison, S. P., Prentice, I. C., Buitenhuis, E. T., Aumont, O., Bopp, L., Claustre, H., Da Cunha, L. C., Geider, R., Giraud, X., Klaas, C., Kohfeld, K. E., Legendre, L., Manizza, M., Platt, T., Rivkin, R. B., Sathyendranath, S., Uitz, J., Watson, A. J., and Wolf-Gladrow, D.: Ecosystem dynamics based on plankton functional types for global ocean biogeochemistry models, Global Change Biology, 11, 2016-2040, 2005.

Madec, G., Delecluse, P., Imbard, M., and Lévy, C.: OPA8.1 Ocean general circulation model reference manual, Notes du pôle de modélisation, IPSL, 1998.

Maier-Reimer, E.: Geochemical cycles in an ocean general circulation model. Preindustrial tracer distributions, Global Biogeochem. Cycles, 7, 645-677, 1993.

Martin, J. H., Knauer, G. A., Karl, D. M., and Broenkow, W. W.: VERTEX: carbon cycling in the northeast Pacific, Deep Sea Res., 34, 267-285, 1987.

McCave, I. N.: Size spectra and aggregation of suspended particles in the deep ocean, Deep-Sea Res., 31(4), 329-352, 1984.

Milliman, J. D. and Droxler, A. W.: Neritic and pelagic carbonate sedimentation in the marine environment: ignorance is not bliss, Geologische Rundschau, 85, 496-504, 1996.
Milliman, J. D., Troy, P. J., Balch, W. M., Adams, A. K., Li, Y.H., and Mackenzie, F. T.: Biologically mediated dissolution of calcium carbonate above the chemical lysocline, Deep Sea Res. I, 46, 1653-1669, 1999.

Moore, K. J., Doney, S. C., and Lindsay, K.: Upper ocean ecosystem dynamics and iron cycling in a global threedimensional model, Global Biogeochem. Cycles, 18, GB4028, doi:10.1029/2004GB002220, 2004.

Passow, U.: Switching perspectives: Do mineral fluxes determine particulate organic carbon fluxes or vice versa?, Geochem. Geophys. Geosyst., 5, Q04002, doi:10.1029/2003GC000670, 2004.

Passow, U. and De La Rocha, C. L.: Accumulation of mineral ballast on organic aggregates, Global Biogeochem. Cycles, 20, GB1013, doi:10.1029/2005GB002579, 2006.

Seiter, K., Hensen, C., and Zabel, M.: Benthic carbon mineralization on a global scale, Global Biogeochem. Cycles, 19, GB1010, doi:10.1029/2004GB002225, 2005.

Stemmann, L., Jackson, G. A., and Ianson, D.: A vertical model of particle size distributions and fluxes in the midwater column that includes biological and physical processes - Part I: model formulation, Deep Sea Res. I, 51, 865-884, 2004a.

Stemmann, L., Jackson, G. A., and Gorsky, G.: A vertical model of particle size distributions and fluxes in the midwater column that includes biological and physical processes - Part II: application to a three year survey in the NW Mediterranean Sea, Deep Sea Res. I, 51, 885-908, 2004b.

Suess, E.: Particulate organic carbon flux in the oceans - Surface productivity and oxygen utilization, Nature, 288, 258-263, 1980.

Taylor, K. E.: Summarizing multiple aspects of model performance in a single diagram, J. Geophys. Res., 106, 28 033-28 059, 2001.

Tréguer, P., Nelson, D. M., van Bennekom, A. J., DeMaster, D. J., Leynaert, A., and Quéguiner, B.: The balance of silica in the world ocean: a re-estimate, Science, 268, 375-379, 1995.

Tréguer, P.: Silica and the cycle of carbon in the ocean, C. R. Geoscience, 334, 3-11, 2002.

Usbeck, R., Schlitzer, R., Fischer, G., and Wefer, G.: Particle fluxes in the ocean: Comparison of sediment trap data with results from inverse modeling, J. Mar. Sci., 39, 167-183, 2003.

Volk, T. and Hoffert, M. I.: Ocean carbon pumps, analysis of relative strengths and efficiencies in ocean-driven atmosphere $\mathrm{CO}_{2}$ changes, in: The Carbon Cycle and Atmospheric $\mathrm{CO}_{2}$ : Natural Variations Archean to Present, edited by: Sundquist, E. T. and Broecker, W. S., Geophys. Monogr., AGU, Washington, D.C., 32, 99-110, 1985.

Yu, E.-F., François, R., Bacon, M. P., Honjo, S., Fleer, A. P., Manganini, S. J., Rutgers van der Loeff, M. M., and Ittekot, V.: Trapping efficiency of bottom-tethered sediment traps estimated from the intercepted fluxes of 230Th and 231Pa, Deep Sea Res. I, 48, 865-889, 2001. 